\title{
POTENTIAL OCCUPATIONAL HEALTH EFFECTS OF MUNICIPAL SOLID WASTE MANAGEMENT IN NIGERIA, THE CASE OF LAGOS AND IBADAN
}

\author{
Adebola A. Adeyi* and Adewale M. Adeyemi \\ Department of Chemistry, University of Ibadan, Ibadan, Nigeria. \\ *Corresponding Author: E-mail Address: bolaoketola@yahoo.com, \\ Tel. No.: +234 8037763961 \\ (Received: $15^{\text {th }}$ May, 2019; Accepted: $19^{\text {th }}$ June, 2019)
}

\section{ABSTRACT}

\begin{abstract}
Municipal Solid Waste Management (MSWM), which include generation of wastes, collection, transportation, recycling and reuse, and disposal poses threat to humans especially the waste handlers and managers and the entire ecosystem. In this study, relevant data and information about the health hazards associated with MSWM were gathered using structured questionnaires administered to three different categories of municipal solid waste (MSW) handlers namely; Domestic Waste Handlers (DWHs), Highway Waste Managers (HWMs) and Dumpsite Waste Managers and Scavengers (DWMSs) in Lagos and Ibadan. Site visits and interviews were conducted to evaluate the general health status of the waste managers and the current MSWM practises in the cities. The results showed that personal protective equipment were not used by many of the managers; wastes were not segregated at the point of generation and/or collection, waste from different sources such as industrial, agricultural, household, commercial etc., some of which contained hazardous materials were codisposed in open dumpsites. Thus, exposure of solid waste managers to hazardous substances in the waste stream was apparent, which might cause diseases such as skin infections among others as a result of improper and unsustainable MSWM. The lack of and none usage of personal protective equipment alongside with the ignorance of the waste handlers may results in occupational health hazards associated with MSWM. These people had suffered for ailments from occupational exposure to toxic, hazardous and infectious substances present in the waste stream. Hence, the needs for proper training, awareness raising and enlightenment of the waste handlers on the risks and health hazards of improper protection and haphazard solid waste management. The need for sustainable and integrated waste management is recommended.
\end{abstract}

Keywords: Municipal solid waste, Health hazard, Dumpsite, Waste handler, Waste management

\section{INTRODUCTION}

Management of municipal solid wastes (MSW) is a priority for urban communities throughout the world (Huang and Chang, 2003; Thakur et al., 2018). Population growth and economic development have brought increasing amounts of solid waste to urban areas (Cointreau, 2006; Rana et al., 2017). Urban solid waste management is considered to be one of the most serious environmental problems confronting urban areas in developing countries (Afroz et al., 2011). It was reported that MSW challenges are going to be enormous or even greater than the challenges we are facing with climate change (World Bank, 2012). Municipal solid waste management (MSWM) is largely accepted as a complex environmental service and involves at least three stages: collection, transportation, and treatment and disposal (Thakur et al., 2018). Collection of MSW produces several types of environmental impact due to the production and use of different types of bags and containers, the use of transport vehicles and the construction, maintenance and demolition of transfer stations (Rives et al., 2010). Inappropriate solid waste operation, storage, collection and disposal practices entail environmental and public health risks (World Resources Institute, 1996). Lack of proper municipal waste segregation and transportation techniques has increased the potential for the transmission of pathogens such as hepatitis B virus (HBV) (Sawyerr et al., 2016). Direct health risks mainly concern those working in the field without using proper gloves, uniform and other personal protective equipment. High percentage of waste workers and individuals who live near or on disposal sites are infected with gastrointestinal parasites, worms, and related organisms (Majumdar and Srivastava, 2012). The lack of provisions and none usage of protective equipment alongside with the ignorance of the waste handlers results in occupational health hazards due to different types of external injuries (Thakur et al., 2018). About 22 human diseases are 
418 Adebola and Adewale: Potential Occupational Health Effects of Municipal Solid Waste Management

linked to improper solid waste management. Because of poverty and lack of environmental regulations and enforcement, disposal in many developing countries is still predominately by open dumping, often with associated open burning (Cointreau, 2006), which creates thick smoke that contains carbon monoxide, carbon dioxide, soot and nitrogen oxides, all of which are hazardous to human health, degrade urban air quality and contribute to global warming. The generation of waste and the collection, processing, transport and disposal is important for both the health of the public and aesthetic, and environmental reasons (Rushton, 2003; El-Wahab et al., 2014). All activities in MSWM involves hazard either to waste handlers directly, or nearby residents.

Waste handlers including collection workers and waste dumpsite managers face particular occupational hazards, including strains from lifting, injuries from sharp objects and contact with pathogens when manually handling the wastes (Patil and Kamble, 2017). They are exposed to a wide variety of health hazards, which can occur via skin contact, injection, ingestion and inhalation (Health and Safety Executive, 2007; Tchobanoglous and Kreith, 2002; Suleman et al., 2015). However, there is some evidence of significant health effects on workers in certain waste sites, which emphasises the need for strong occupational exposure limits to hazardous materials and the necessity for good personal protective equipment (Environmental Health Division, 2005).

In Nigeria, the state government is responsible for the protection of the environment and in accordance with Nigerian constitution; MSWM is one of the functions of the State Government. Consequently, Lagos State and Oyo State
Governments established the Lagos State Waste Management Agency and Oyo State Solid Waste Management Authority, respectively to manage MSW. These agencies have introduced various reform measures on waste management. However, human health risks associated with MSWM is not well guided and contrived. Thus, this study assesses the human health impacts of current MSWM in Nigeria using Lagos and Ibadan as case study so as to ascertain the potential occupational health hazards associated with occupational exposure of different waste handlers and managers to different hazardous substances present in MSW stream.

\section{DATA GATHERING METHODS}

\section{Description of the Study Areas}

Lagos state is located in the Southwest mouth of Lagos lagoon on latitude $6^{0} 27^{1} 11.651^{11} \mathrm{~N}$ and longitude $3^{0} 23^{1} 45.801^{11} \mathrm{E}$. Lagos is the second fastest growing city in Africa with an average annual growth rate of $4.44 \%$ after Bamako, Mali with an average annual growth rate of $4.45 \%$. The 2006 population census of the National Population Commission in Nigeria estimated Lagos population at 7,937,932 people (National Population Commission, 2008). Ibadan is located in the Southwest Nigeria on latitude $7^{0} 23^{1} 16.008^{11}$ $\mathrm{N}$ and longitude $3^{0} 53^{1} 47.004^{11} \mathrm{E}$ in Oyo State of Nigeria. It is geographically the biggest city in Nigeria with a population of $3,565,810$ people (National Population Commission, 2008). It is the fourth fastest growing city in Nigeria with an average annual growth rate of $2.20 \%$ after Lagos (4.44\%), Kaduna $(2.40 \%)$ and Kano $(2.34 \%)$ (City Mayors, 2010). Figures 1 and 2 shows the map of Lagos and Ibadan, respectively while Table 1 shows the characteristics of the dumpsites in the two cities. 


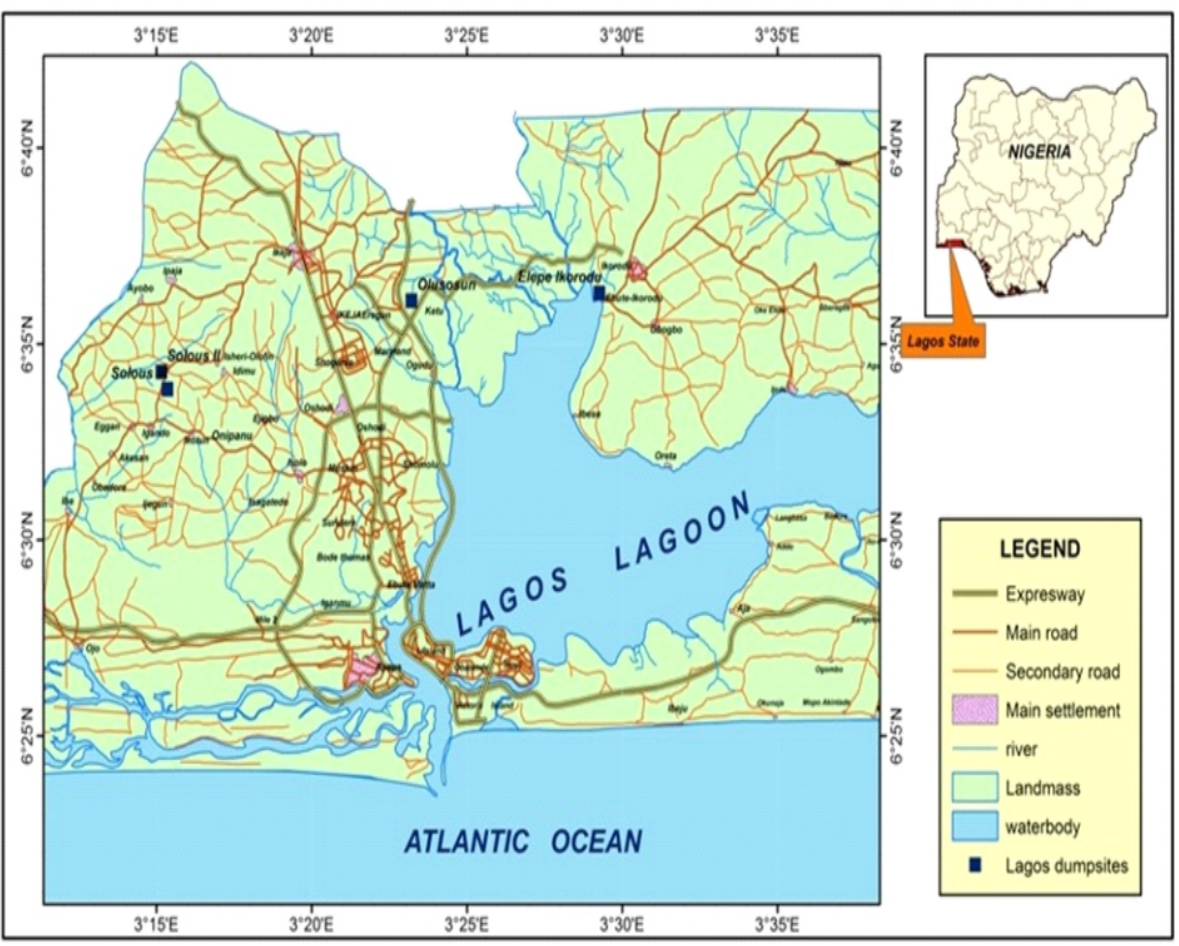

Figure 1: Map of Lagos State showing the four dumpsites considered in this study

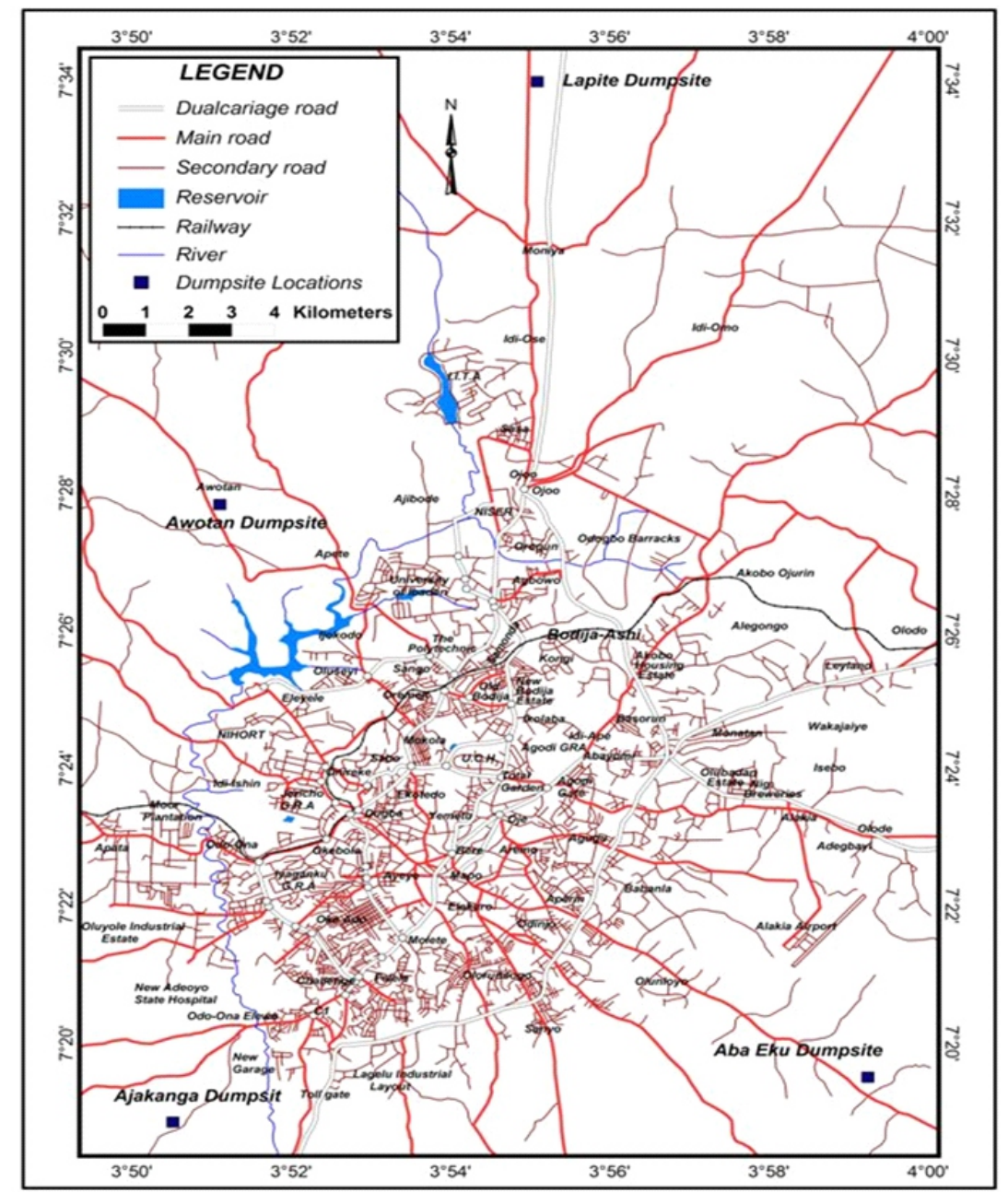

Figure 2: Map of Ibadan showing the four dumpsites considered in this study 
Adebola and Adewale: Potential Occupational Health Effects of Municipal Solid Waste Management

Table 1: Characteristics and coordinates of dumpsites in Lagos and Ibadan

\begin{tabular}{|c|c|c|c|c|c|}
\hline Dumpsites & Site codes & Location/City & $\begin{array}{c}\text { Co-ordinates } \\
\text { (Longitudes/Latitudes) }\end{array}$ & $\begin{array}{c}\text { Size } \\
\text { (Hectares) }\end{array}$ & $\begin{array}{c}\text { Age } \\
\text { (Years) }\end{array}$ \\
\hline \multicolumn{6}{|l|}{ Lagos } \\
\hline Olusosun & OLD & Ojota, Lagos & $\begin{array}{l}\text { N06'35'781.0, } \\
\text { E003'22'657.0 }\end{array}$ & 42 & 39 \\
\hline Solous 2 & SLD2 & Igando, Lagos & $\begin{array}{l}\text { N06³4'27.0, } \\
\text { E 00315'101 }\end{array}$ & 10 & 25 \\
\hline Solous 3 & SLD3 & Igando, Lagos & $\begin{array}{l}\text { N06 }^{\circ} 33^{\prime} 837.0, \\
\text { E 003'15'186 }\end{array}$ & 10 & 25 \\
\hline $\begin{array}{l}\text { Owutu- } \\
\text { Elepe, }\end{array}$ & $\mathrm{IKD}$ & Ikorodu, Lagos & $\begin{array}{l}\text { N06'34'271.0, } \\
\text { E 003'34'835 }\end{array}$ & 30 & 35 \\
\hline \multicolumn{6}{|l|}{ Ibadan } \\
\hline Awotan & AWD & Apete, Ibadan & $\begin{array}{c}\text { N07'027'041.9, } \\
\text { E } 003 \circ 50^{\prime} 54.0\end{array}$ & 20 & 16 \\
\hline Lapite & LPD & Akinyele, Ibadan & $\begin{array}{l}\text { N07०34'09.9, } \\
\text { E 003०54'39.4 }\end{array}$ & 25 & 19 \\
\hline Aba-Eku & AED & Aba-Eku, Ibadan & $\begin{array}{l}\text { N07०54'18.0, } \\
\text { E 003०74'8.0 }\end{array}$ & 20 & 21 \\
\hline Ajakanga & $\mathrm{AKD}$ & Ring Road, Ibadan & $\begin{array}{l}\text { N07 o18'51 } \\
\text { E003 ॰50'31 }\end{array}$ & 10 & 10 \\
\hline
\end{tabular}

\section{Categories of Solid Waste Managers and their Functions}

In this study, municipal solid waste handlers and managers were categorized into three groups based on their duties and functions, namely:

\section{Domestic Waste Handlers (DWHs):}

Domestic waste handlers manually collects the solid waste generated at houses, streets, offices, shops, institutions and dump it in the bins at specified locations in the house or street corners. Some DWH are employees of firms under contract to institutions, hotels, companies, commercial centres, schools etc.

\section{ii. Highway Waste Managers (HWMs):}

Highway waste managers (HWMs) uses waste disposal vehicles for the collection of solid wastes, which has been deposited in solid waste bins and transport it to disposal sites and open dumpsites. Manual or mechanical loading compactors are used to transfer the solid wastes into disposal vehicles e.g. trucks, compacter vehicles etc.

iii. Dumpsite Waste Managers and Scavengers (DWMSs): Dumpsite Waste Managers and Scavengers (DWMSs) include employees of waste management agencies that manage the dumpsites and solid waste scavengers at the dumpsites. Employees of the waste management agencies regulate, monitor and control the dumping of solid wastes at the dumpsites while scavengers salvage repairable, reusable and rentable solid wastes from the dumpsites for small scale recycling and reuse. Scavengers target valuable materials such as plastics, paper, glass, metals etc. Their activities have great impact on the reduction of the net volume of solid wastes that remaining on the dumpsites.

\section{Questionnaire Administration and Site Survey}

Three different questionnaires were designed and administered to DWHs, HWMs and DWMSs, respectively. The questionnaires were used to collect information that is relevant to solid waste management, health status and impacts of MSWM. One hundred and forty (140) DWHs, 114 HWMs and 93 DWMSs in Lagos and Ibadan were the respondents. The questionnaires were designed to obtain the following information;

i. General background information, which include name of their company, years of service as solid waste handlers and managers, level of education etc.

ii. Waste management information such as type of solid waste managed, solid waste 
management processes, materials/equipment used for solid waste management (plastic containers, metal containers, truck, trash compacter) etc.

iii. Protective measures taken during solid waste management such as the use of personal protective equipment such as gloves, rubber boot, nose cover, apron etc.

iv. Health status, impacts of solid waste management and occupational exposure such as difficulty in breathing, asthmatic attack, cough, dysentery, typhoid, cholera, hearing difficulties, skin diseases etc.

v. Measures to reduce the health effects such as reduction in emission exposure, provision and use of personal protective kits and equipment, health insurance, vaccination against infectious diseases, vehicle maintenance, and provision of first aid materials etc.

\section{Statistical Analysis}

Descriptive statistics such as frequency, and Analysis of Variance (ANOVA) were used for data analysis.

\section{RESULTS AND DISCUSSION}

The information obtained from questionnaire administered to 140 DWHs, 114 HWMs and 93 DWMSs in Lagos and Ibadan are presented in Table 2.

\section{Solid waste generation and management in Lagos and Ibadan}

Solid waste management has been associated with health impacts and hazards either to the waste handlers and managers directly/indirectly or to the environment. Health hazards and effects occur at every step in the process of solid waste management, from the point of collection, to recycling and to the point of final disposal and treatment. Solid waste production has been thought to be a function of population. This study revealed that the MSW generated in Lagos and Ibadan was mainly from household, commercial, agricultural, healthcare and industrial sources. The Lagos State Waste Management Authority recorded a monthly average of approximately $323,961.47$ cubic meters of solid waste disposed in the five approved dumpsites namely; Olushosun, Soluos II, Soluos III, Owutu-Elepe and Temu from January to October 2013. Information from Oyo State Solid Waste Management Authority also showed a monthly average of 49,438.24 cubic meters of solid waste disposed in the four approved dumpsites namely; Ajakanga, Aba-Eku, Awotan and Lapite from January to October 2013. Also, the percentage composition of solid wastes from the dumpsites in Lagos and Ibadan have been estimated to composed of approximately $85 \%$ domestic and $15 \%$ industrial wastes and $90 \%$ domestic and less than $10 \%$ industrial wastes, respectively (Oketola and Akpotu, 2015; Adeyi and Adeyemi, 2017).

\section{Educational qualification}

The educational qualification of the waste handlers and managers varied in Lagos and Ibadan.

The study revealed that $71.9 \%$ of DWHs, $75 \%$ of HWMs and $50 \%$ of DWMs and scavengers interviewed in Lagos (Table 3) were at least secondary school certificate holders while $28.9 \%$ of the DWHs, $74.1 \%$ of HWMs and $48.9 \%$ of DWMSs in Ibadan (Table 3) were at least secondary school certificate holders. However, $3.9 \%$ of DWHs and $1.7 \%$ of HWMs in Ibadan and $3.1 \%$ of DWHs and 3.6\% of HWMs in Lagos had no formal education, which may adversely affect their understanding of the concepts and rudiments of safe waste management practices. 
Adebola and Adewale: Potential Occupational Health Effects of Municipal Solid Waste Management

Table 2: Distribution of solid waste handlers and managers interviewed in Lagos and Ibadan

\begin{tabular}{|l|c|c|c|}
\hline Location & $\begin{array}{c}\text { Domestic waste } \\
\text { handlers (DWHs) }\end{array}$ & $\begin{array}{c}\text { Highway waste } \\
\text { managers (HWMs) }\end{array}$ & $\begin{array}{c}\text { Dumpsite waste } \\
\text { managers (DWMs) }\end{array}$ \\
\hline Ibadan & 76 & 58 & 45 \\
\hline Lagos State & 64 & 56 & $\mathbf{9 3}$ \\
\hline Total & 140 & 114 & 48 \\
\hline
\end{tabular}

Table 3: Educational status of Solid Waste Handlers and Managers in Lagos and Ibadan

\begin{tabular}{|c|c|c|c|c|c|c|}
\hline \multirow[b]{2}{*}{ Lagos } & \multicolumn{2}{|c|}{ Domestic Waste Handlers (DWHs) } & \multicolumn{2}{|c|}{$\begin{array}{l}\text { Highway Waste Managers } \\
\text { (HWMs) }\end{array}$} & \multicolumn{2}{|c|}{$\begin{array}{l}\text { Dumpsite Waste Managers } \\
\text { and Scavengers (DWMSs) }\end{array}$} \\
\hline & Frequency & Percentage & Frequency & Percentage & Frequency & Percentage \\
\hline Not educated & 2 & 3.1 & 2 & 3.6 & - & 0 \\
\hline Primary School Certificate Holders & 15 & 23.4 & 12 & 21.4 & 24 & 50 \\
\hline $\begin{array}{l}\text { Junior Secondary School Certificate } \\
\text { Holders }\end{array}$ & 1 & 1.6 & - & 0 & - & 0 \\
\hline $\begin{array}{l}\text { Senior Secondary School } \\
\text { Certificate Holders }\end{array}$ & 46 & 71.9 & 42 & 75 & 24 & 50 \\
\hline Ibadan & & & & & & \\
\hline Not educated & 3 & 3.9 & 1 & 1.7 & - & 0 \\
\hline Primary School Certificate Holders & 51 & 67.1 & 14 & 24.1 & 23 & 51.1 \\
\hline $\begin{array}{l}\text { Senior Secondary School Certificate } \\
\text { Holders }\end{array}$ & 22 & 28.9 & 43 & 74.1 & 22 & 48.9 \\
\hline
\end{tabular}

\section{Current solid waste management practices}

\section{Waste segregation and transportation}

The study revealed that solid wastes collected in Lagos and Ibadan were not segregated at the point of generation and or collection, which made sorting difficult because all the solid wastes were mixed together and some of them may contain hazardous substances as MSW from different sources were co-disposed. Transportation of solid wastes generated in Ibadan to the approved dumpsites by HWMs were carried out using trucks $(46.6 \%)$ and trash compactor vehicles $(55.2 \%)$ provided by the eleven Local Government Areas in Ibadan and Oyo State Solid Waste Management Authority while in Lagos, solid wastes were transported using trash compactor vehicles $(100 \%)$. Trash compactor vehicles have the capability to carry more quantity of solid wastes than trucks. Thus, reduces the number of trips required for the transportation of solid wastes to the dumpsites and also aid covering of most areas for waste collection and subsequent transportation to the dumpsites.

\section{Waste processing and treatment}

About $98.2 \%$ of HWMs in Lagos covered the solid waste collected during transportation to the dumpsites while $96.6 \%$ of HWMs in Ibadan covered the solid wastes collected in the trucks. Covering the solid wastes during transportation to the dumpsites will help to prevent falling of the wastes and therefore enhances the aesthetic value of the city. Metals, plastics, glass bottles, rubbers, nylons (Figure 3) were some of the valuable materials normally recovered from the MSW streams by scavengers in both cities. These repairable, reusable and rentable materials were 
Adebola and Adewale: Potential Occupational Health Effects of Municipal Solid Waste Management

packed and sold to some artisans and small-scale industries that received their raw materials from solid wastes. In Olushosun dumpsite, the solid wastes dumped was usually covered or buried with topsoil (Figure 4) to eliminate the harbouring of disease vectors, to enhance the aesthetic appearance of the site and to limit the amount of leachate infiltration, thus protecting the groundwater from pollution.

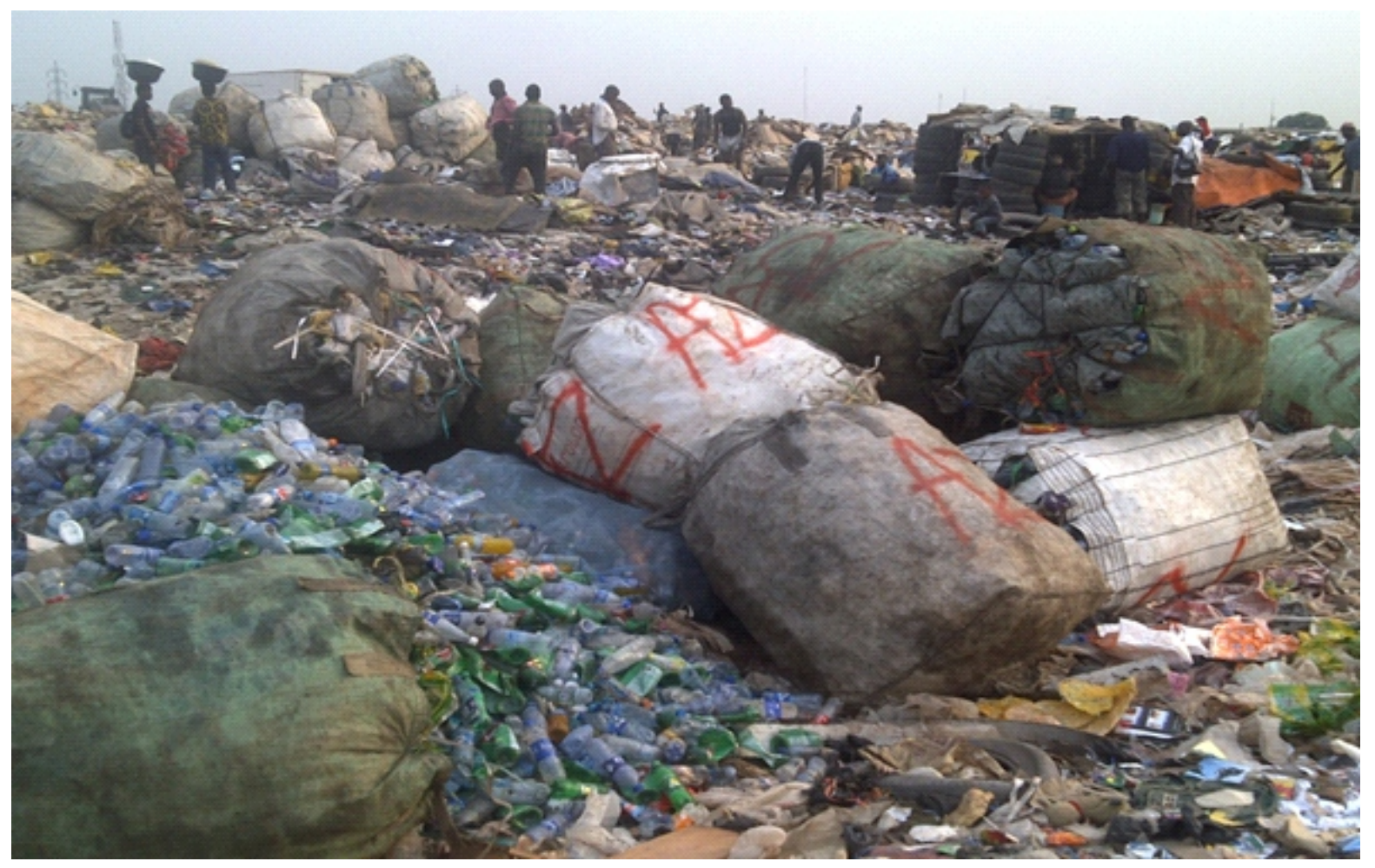

Figure 3: Recovered materials at Solous II dumpsite in Lagos

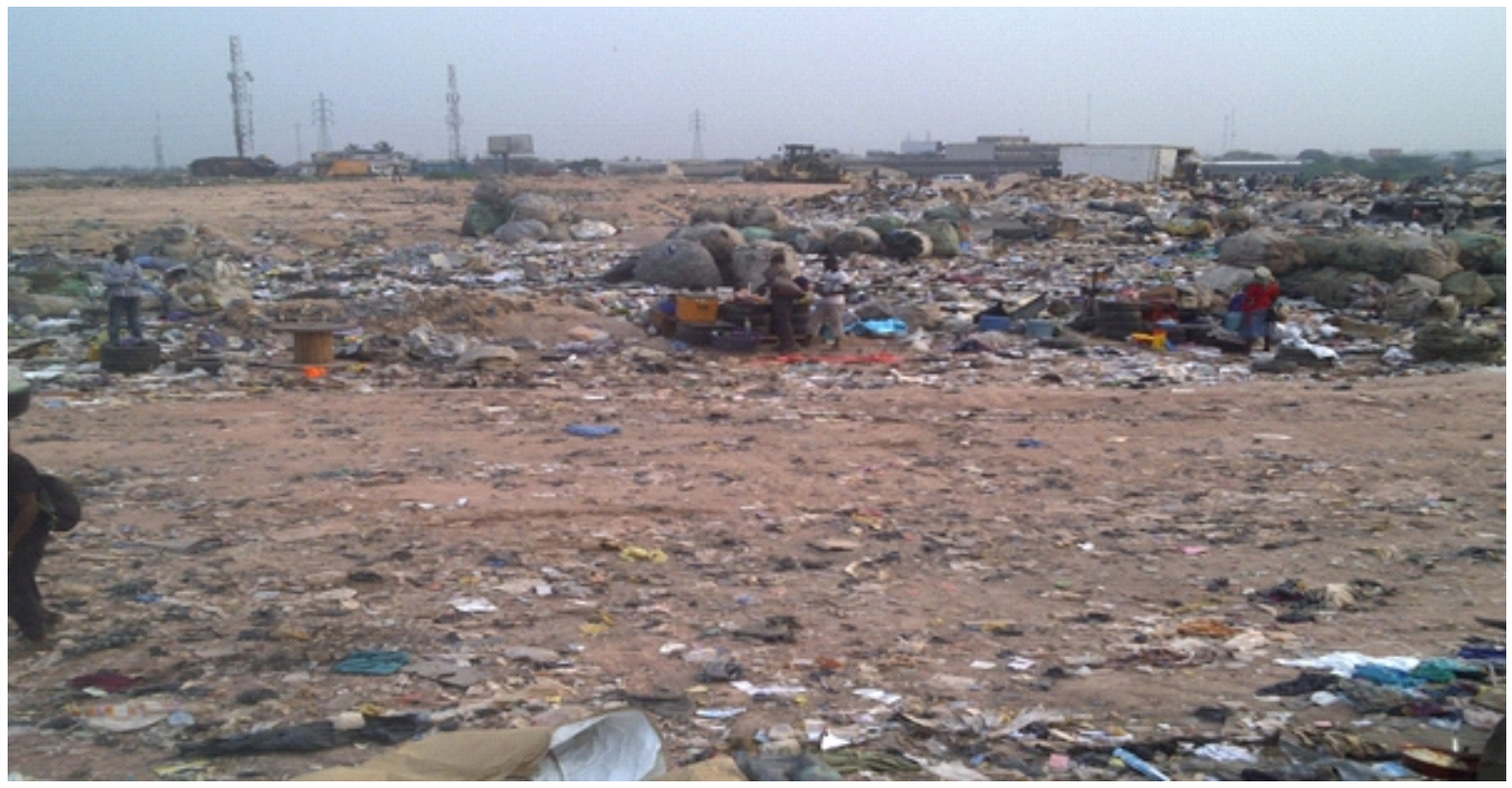

Figure 4: Solid wastes at Olushosun dumpsite covered with topsoil 
Questionnaire survey revealed that DWMs in all the eight dumpsites does not set fire on the solid wastes. However, fire may result from various chemical products in the solid wastes, which may combine and react. Cans of gasoline or kerosene and exploding aerosol cans that have been heated and contain butane or toluene may act as an accelerant, increasing the intensity and spread rate of fire (Tchobanoglous and Kreith, 2002). The study also revealed that there is no leachate treatment facility in all the dumpsites. Therefore, biological and chemical materials that are leached into water percolating through solid wastes that are undergoing decomposition (leachate) was not treated and may finally contaminate the groundwater and affect the surrounding environment. Previous study have shown that a large number of compounds, many of which are hazardous to human health and the environment, are present in dumpsites leachate and topsoil in Nigeria (Oketola and Akpotu, 2015). Some of the compounds such as heavy metals, polycyclic aromatic hydrocarbons, and polychlorinated biphenyls are persistent, bio-accumulate, and travel long distance. Also, some have been shown to be endocrine disruptors, carcinogenic and mutagenic.

\section{Use of personal protective equipment}

The MSW generated in Nigeria are usually mixed with other wastes from industrial, commercial and agricultural sources. Among the different waste managers considered in this study in Lagos and Ibadan, lack of and none usage of personal protective equipment (PPE) were common and noticed as shown in Figure 5( $a$ and $b$ ). Among the waste managers, Domestic Waste Handlers (DWHs) had the highest percentages of none usage of all the PPE (gloves, apron, rubber boots and nose cover) in both Lagos and Ibadan except Dumpsite Waste Managers and Scavengers (DWMSs) in Lagos and Highway Waste Managers (HWMs) in Ibadan among which none usage of apron was the highest. The percentage none usage of PPE among all the different waste managers in Ibadan was higher than what was obtained in Lagos. This might be attributed to their levels of education and understanding of the risk associated with their occupation. In Lagos, $71.9 \%$ of the DWHs had undergone Senior Secondary School while it was only $28.9 \%$ in Ibadan. It was therefore evident that DWHs are susceptible to health hazards and impacts of haphazard waste management due to the lack of usage of appropriate protective equipment. It was reported that majority $(91.7 \%)$ of the municipal waste management workers in Ilorin, Nigeria did not use PPE (Sawyerr et al., 2016). Though, usage of protective gears cannot prevent exposure to different kinds of injuries, its regular use by the waste handlers will significantly reduce the chances of exposure to hazardous substances present in the waste stream (Thakur et al., 2018). 
Adebola and Adewale: Potential Occupational Health Effects of Municipal Solid Waste Management

(a)

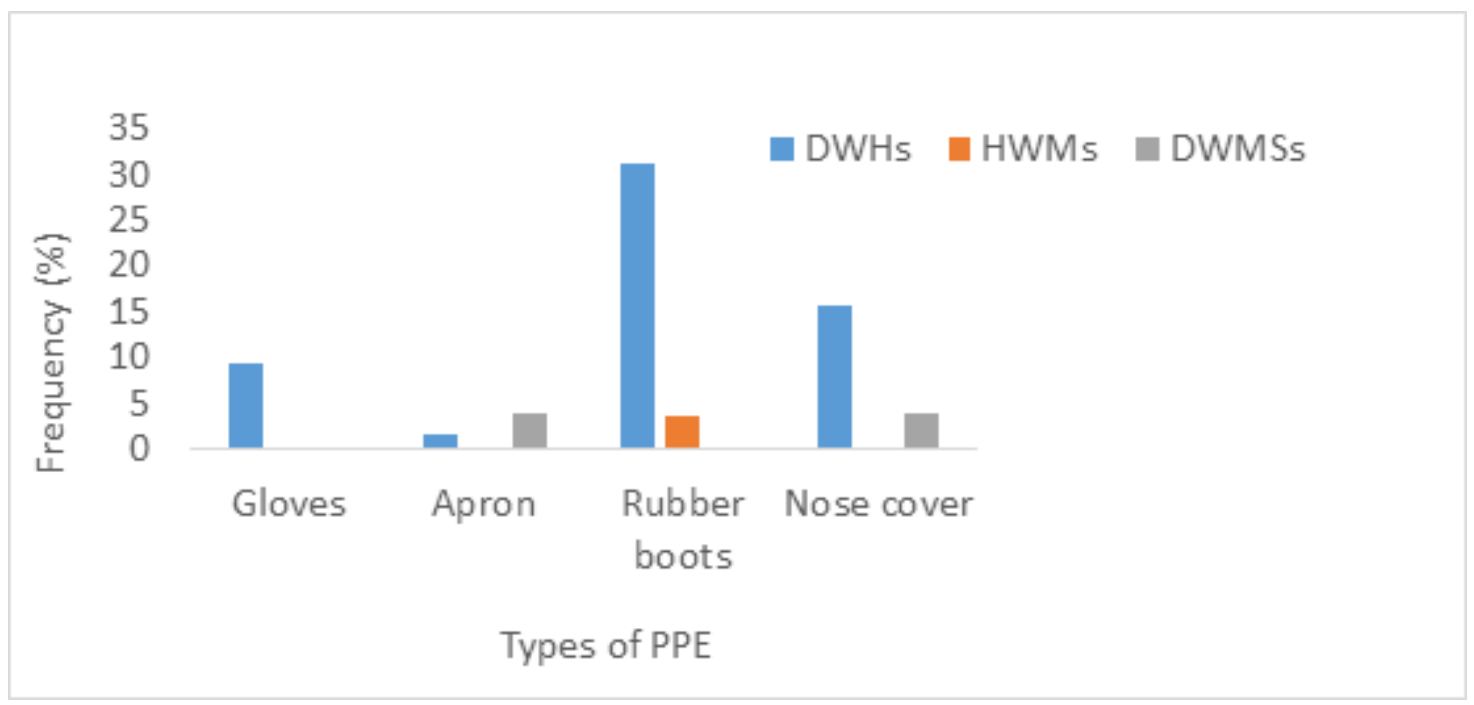

(b)

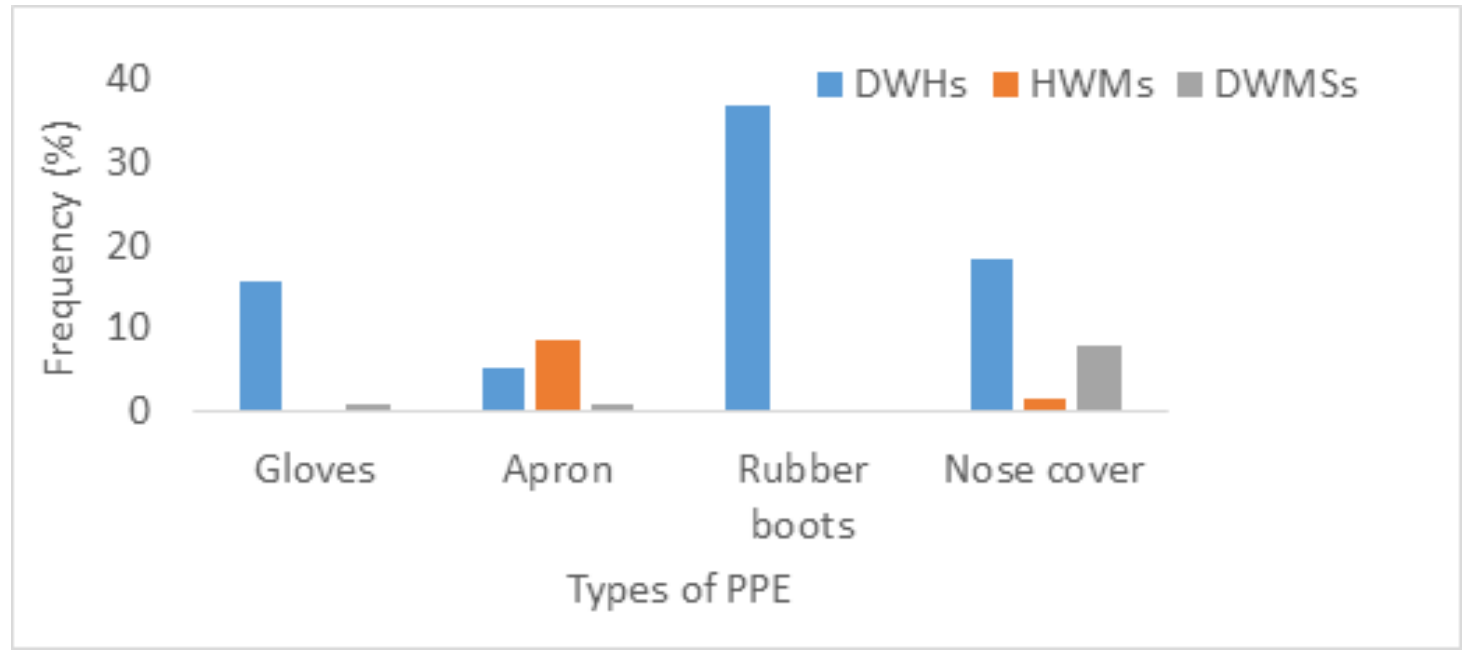

Figure 5: Distribution of none usage of PPE among the waste managers in (a) Lagos and (b) Ibadan

The levels of hygiene among the waste managers in Lagos and Ibadan also differs as presented in Figure 6. It was very uncommon among all the waste managers to eat while on duty. In Lagos, $89 \%$ and $64.3 \%$ of the DWHs and HWMs, respectively do not eat while carrying out their duties (Figure $6 \mathrm{a}$ ) while in Ibadan, it was $68.4 \%$ of DWHs and $89.7 \%$ of HWMs (Figure $6 \mathrm{~b}$ ). This showed that these category of waste managers observed high level of hygiene while on duty. In Lagos, $71.8 \%$ of DWHs, $35.7 \%$ of HWMs and $35 \%$ of DWMSs did not have routine medical checks while it was $27.6 \%, 58.6 \%$ and $26 \%$ of the DWHs, HWMs, and DWMSs, respectively in Ibadan. None routine medical checks of the health status among the waste managers is very dangerous as they are mostly exposed to different hazardous substances present in the waste. 
(a)

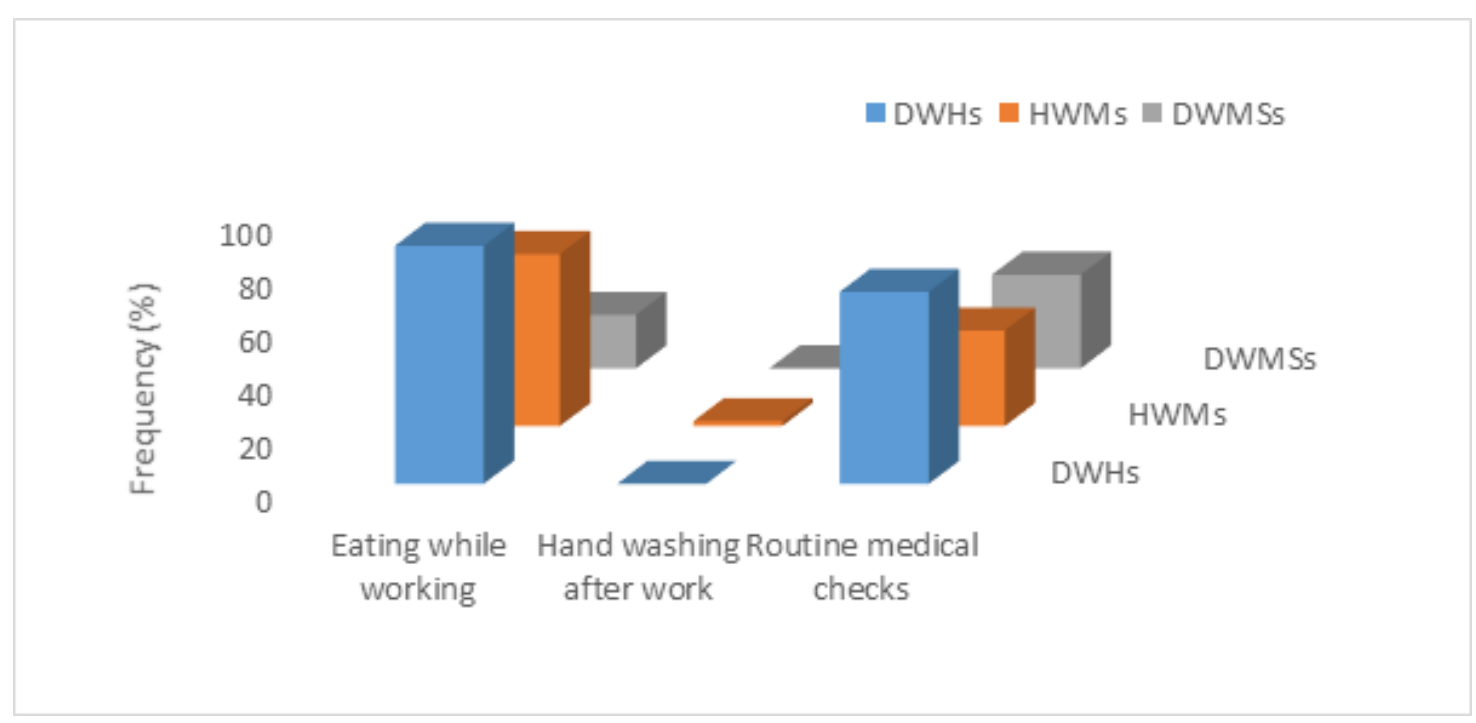

(b)

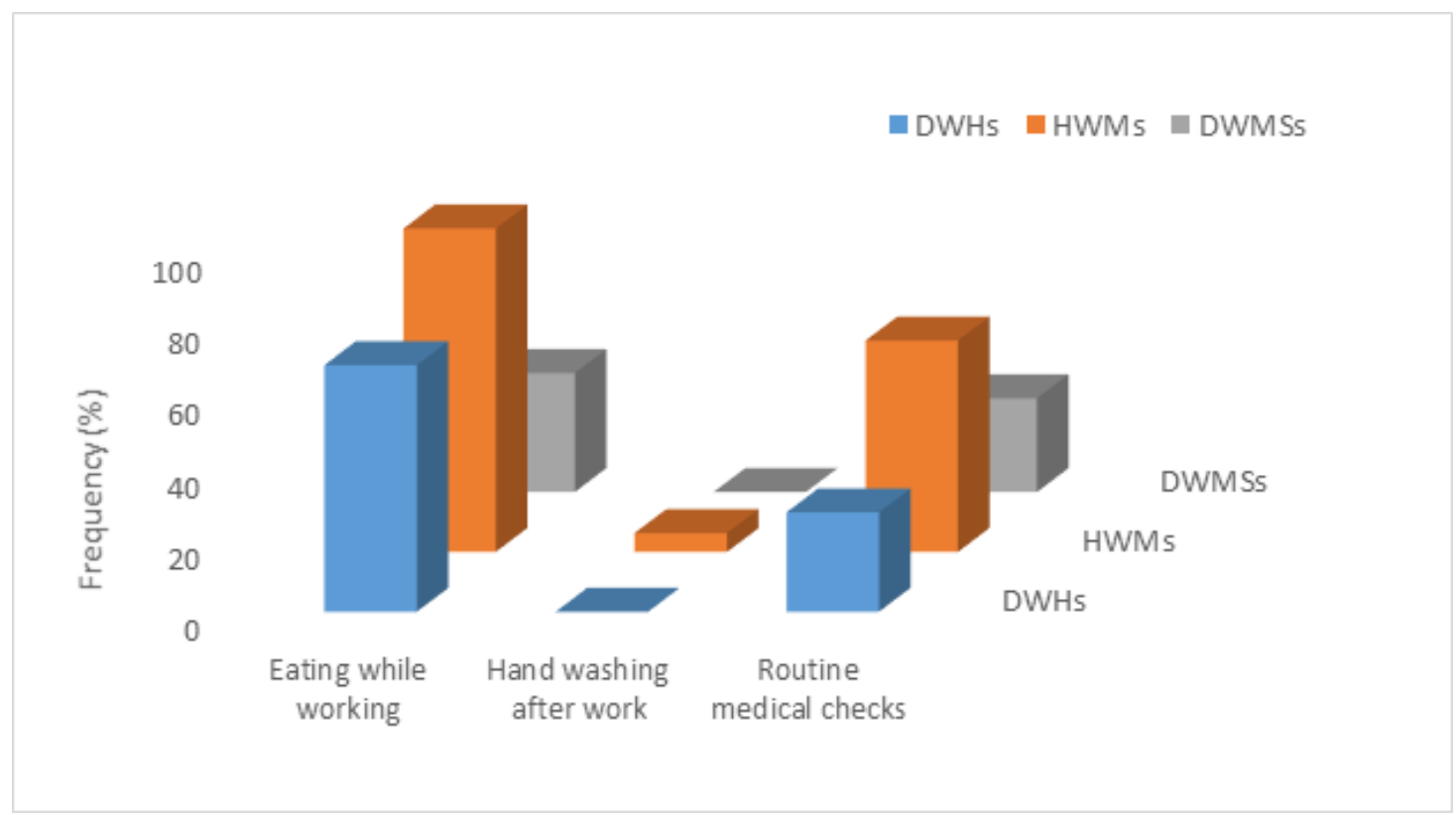

Figure 6: Distribution of levels of hygiene and none routine medical checks among the waste managers in (a) Lagos and (b) Ibadan

\section{Human Health Impacts of MSWM in Lagos and Ibadan}

Waste handlers and managers are exposed to hazardous materials present in MSW stream, thus, suffered for various types of injuries associated with the occupational exposure. Some of the reported health problems in waste workers are musco-skeletal pain, cough, chest tightness, diarrhoea, joint pain, skin irritation, cancer, injuries, puncture wounds, damage to eyes and ears (Poulsen et al., 1995). Furthermore, working conditions of waste workers and handlers are very poor and they do not have any provision for drinking water and sanitation at working place (Agarwal et al., 2005).

Dumpsite Waste Managers and Scavengers (DWMSs) in Ibadan reported several cases of ailments which ranged from cholera (2.6\%), cough $(28.9 \%)$, asthmatic attack $(3.9 \%)$, difficulty in breathing $(1.3 \%)$, and skin diseases $(1.3 \%)$. In Lagos, cough (6.3\%), eye irritation (3.1\%), dysentery $(4.7 \%)$, and typhoid fever $(4.7 \%)$ were 
Adebola and Adewale: Potential Occupational Health Effects of Municipal Solid Waste Management

reported. However, HWMs in Ibadan had several cases of ailments which ranged from skin diseases $(5.2 \%)$, eye irritation $(5.2 \%)$, difficulty in breathing $(1.7 \%)$, cough $(5.2 \%)$, typhoid $(1.7 \%)$, dysentery $(3.4 \%)$, muscle tear $(6.9 \%)$, backache $(8.6 \%)$, fallen off the trash vehicles $(1.7 \%)$, contact with harmful chemicals (10.3\%). Highway Waste Managers (HWMs) in Lagos had the same cases such as skin diseases $(12.5 \%)$, eye irritation $(3.6 \%)$, cough $(1.8 \%)$, typhoid $(1.8 \%)$, and backache $(23.2 \%)$ as shown in Figure 7 . Among the Dumpsite Waste Managers and Scavengers (DWMs) in Lagos, skin diseases (15.4\%), eye irritation $(7.7 \%)$, cough $(28.6 \%)$, typhoid $(28.1 \%)$, dysentery (35.7\%) and cholera (7.14\%) were reported (Figure 7a) while in Ibadan, skin diseases $(10 \%)$, eye irritation $(21.1 \%)$, muscle tear $(35.5 \%)$ and backache (44.4\%) were reported (Figure $7 \mathrm{~b})$.

(a)

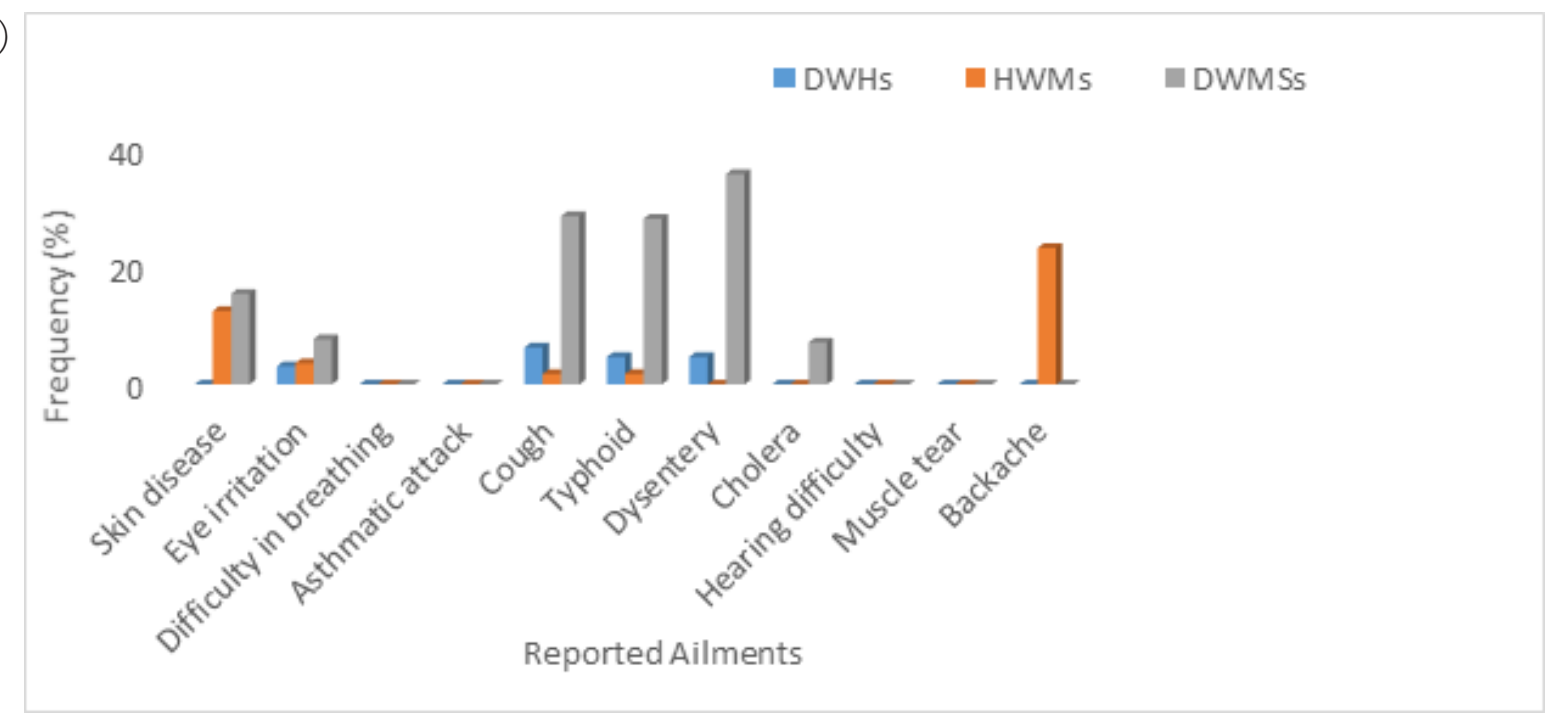

(b)

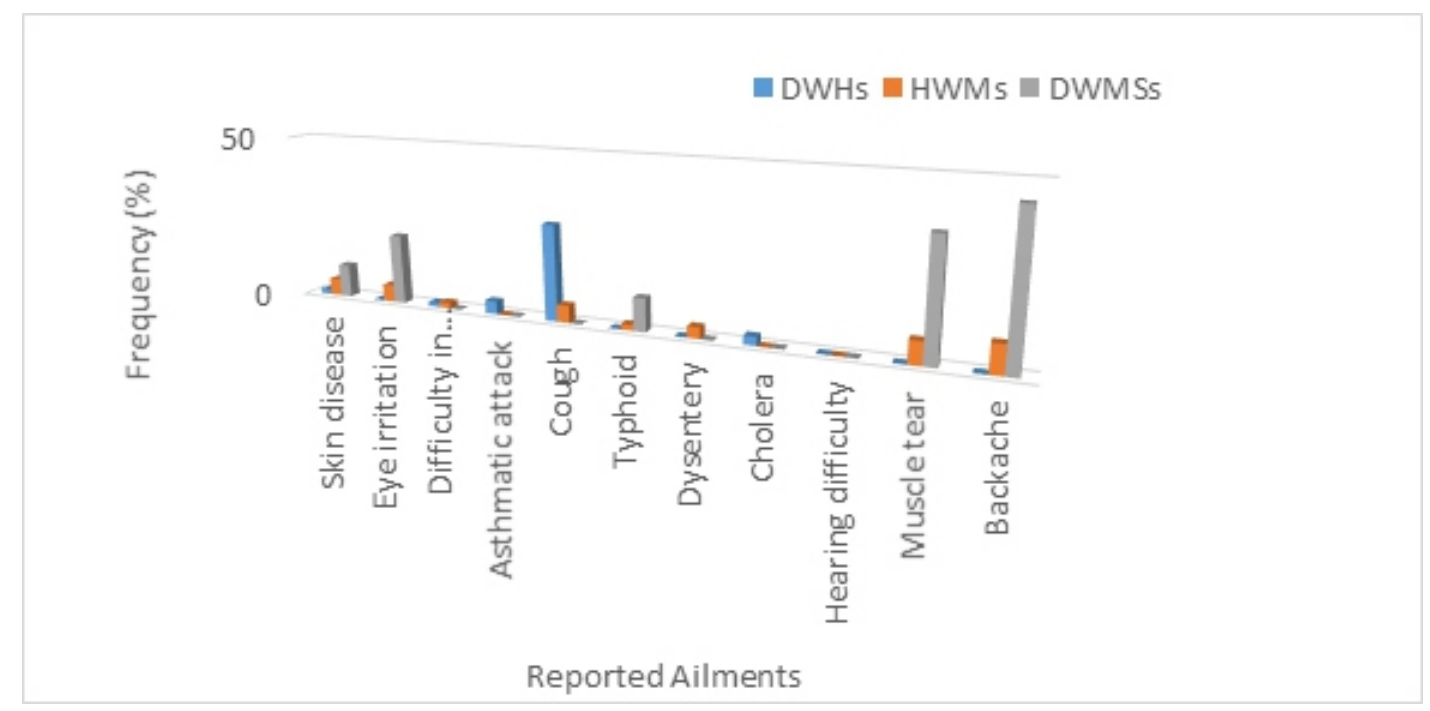

Figure 7: Reported Health Issues and Ailments among the waste managers in (a) Lagos and (b) Ibadan 
This is in contrast with what was reported by Oyeyiola et al. (2011) where $86 \%, 66 \%, 90 \%$, $42 \%, 44 \%, 46 \%$ and $48 \%$ cases of eye irritation, difficulty in breathing, cough, cholera, dysentery, typhoid and asthmatic attack, respectively were reported. The low cases of ailment recorded among the HWMs and DWMSs at Olushosun dumpsite in Lagos (Table 4) may be due to the improvement in solid waste management practices such as use of personal protective equipment, covering of solid wastes with topsoil, prevention of scavengers from living on the dumpsite etc. Some of the diseases reported such as cough, asthmatic attack and difficulty in breathing are air-borne diseases while cholera, typhoid fever and dysentery are water-borne diseases and backaches are stress related ailment. It was reported that municipal waste management workers and scavengers working in dumpsites in Nigeria suffer from health consequences such as frequent fever, malaria, body aches, cuts and bruises and general weakness. They also live in poor housing conditions, often lacking access to a safe water supply and sanitation and are often unaware of the dangers, but are economically dependent on their occupation for their livelihood (Sawyerr et al., 2016; Nzeadibe, 2009; Nzeadibe and Iwuoha, 2008).

However, all the DWHs and HWMs in Lagos and Ibadan had no health insurance scheme which covers the cost of their medical treatment. Thus, $27.6 \%$ of the DWHs in Ibadan do not have routine medical check-up to assess their health status. Several measures required to reduce health hazards includes routine medical checks, provision of protective materials, vaccination against preventable diseases, public awareness on safe solid waste handling practices, provision of first aid materials, provision of new collection vehicles and proper vehicle maintenance.

Table 4: Health challenges among Dumpsite Waste Managers and scavengers(DWMSs) in Lagos dumpsites

\begin{tabular}{|c|c|c|c|c|c|c|c|c|}
\hline \multirow[t]{2}{*}{ Health Ailments } & \multicolumn{2}{|c|}{ Solous II } & \multicolumn{2}{|c|}{ Solous III } & \multicolumn{2}{|l|}{ Elepe } & \multicolumn{2}{|c|}{ Olushosun } \\
\hline & Yes & No & Yes & No & Yes & No & Yes & No \\
\hline & $\mathrm{F}(\%)$ & $\mathrm{F}(\%)$ & $\mathrm{F}(\%)$ & $\mathrm{F}(\%)$ & $\mathrm{F}(\%)$ & $\mathrm{F}(\%)$ & $\mathrm{F}(\%)$ & $\mathrm{F}(\%)$ \\
\hline Skin diseases & - & 100 & - & 100 & - & 100 & 15.4 & 84.6 \\
\hline Eye irritation & - & 100 & - & 100 & - & 100 & 7.69 & 92.3 \\
\hline Difficulty in breathing & - & 100 & - & 100 & - & 100 & - & 100 \\
\hline Asthmatic attack & - & 100 & - & 100 & - & 100 & - & 100 \\
\hline Cough & - & 100 & - & 100 & 28.6 & 71.4 & - & 100 \\
\hline Typhoid & 7.14 & 92.9 & - & 100 & 14.3 & 85.7 & 7.69 & 92.3 \\
\hline Dysentery & 7.14 & 92.9 & 14.3 & 85.7 & 14.3 & 85.7 & - & 100 \\
\hline Cholera & - & 100 & 7.14 & 92.9 & - & 100 & - & 100 \\
\hline
\end{tabular}

Note: $\mathrm{F}=$ Frequency 


\section{RESULTS OF STATISTICAL ANALYSIS}

The data obtained from questionnaire administration were subjected to Analysis of Variance (ANOVA) at $\mathrm{p}<0.05$ using SPSS. The significant health challenges among Dumpsite Waste Managers and Scavengers (DWMSs) and scavengers were typhoid, eye irritation, backache, cough, dysentery, and muscle tear at $\mathrm{p}<0.05$. Backache was the most significant health challenge among Highway Waste Managers (HWMs) while cough was the most significant health challenge among the Domestic Waste Handlers (DWHs) at the same level. The health challenges faced by the DWHs might be attributed to the fact that most of them does not use personal protective equipment such as nose mask and are thus exposed to harmful gaseous and particulate substances at the point of waste collection, which are often not sorted and segregated.

\section{CONCLUSION}

Lack of proper occupational health safety management among municipal solid waste managers was a possible risk factor for hepatitis $B$ virus as reported by Sawyerr et al., (2016) and other infections through injury with sharp instruments in the waste stream. Solid waste managers were not properly trained on safety measures in solid waste management coupled with the fact that protective materials such as gloves, rubber boots and nose cover were not used by many of them even when provided. This may have led to several cases of ailments such as cholera, cough, difficulty in breathing, skin diseases, dysentery, eye irritation, typhoid fever etc. among them. The study however revealed that one out of the 347 solid waste managers interviewed had health insurance facility. Lack of medical insurance scheme for the different categories of solid waste managers is responsible for many of them not having routine medical check-up to take care of their health. Waste managers should be trained on occupational and health safety, awareness on the potential dangers and risks associated with their job when carried out their duties and functions haphazardly, understanding the risks involved through proper information, instruction, training and supervision and promote good personal hygiene and vaccination against hepatitis B virus and other pathogenic infectious will help to control risk of infection among the different categories of municipal solid waste managers and scavengers. Also, low environmental impact waste management systems that are protective of human health and safety should be considered in the country to safeguard the health of the managers, provide appropriate equipment and enforce its usage, as well as regular checks and monitoring of the managers to ensure that the system is working as planned and followed is imperative and highly recommended.

\section{REFERENCES}

Afroz, R., Hanaki, K., and Tudin, R. 2011. Factors affecting waste generation: a study in a waste management program in Dhaka City, Bangladesh. Environ Monit Assess. 179, 509-519.

Agarwal, A., Singhmar, A., Kulshrestha, M., and Mittal, A.K. 2005. Municipal solid waste recycling and associated markets in Delhi, India. Resources, Conservation and Recycling. 44, 73-90.

City Mayors. 2010. World's Fastest Growing Cities and Urban Areas from 2006 to 2020. Retrieved at www.citymayors.com on 28th November 2013.

Cointreau, S. 2006. Occupational and Environmental Health Issues of Solid Waste Management. Special Emphasis on Middle- and Lower- Income Countries. The World Bank, Washington D.C.

El-Wahab, E.W.A., Eassa, S.M., Lotfi, S.E., Masry, S.A.E., Shatat, H.Z., and Kotkat, A.M.,

2014. Adverse health problems among municipality workers in Alexandria (Egypt). Int. J. Prevent. Med. 5 (5), 545-556

Environmental Health Division. 2005. A Review of the Potential Health and Environmental Impacts from Municipal Waste Management Technologies which might be used in Milton Keynes. The Environmental Protection Team, Environmental Health Division Milton Keynes Council, United Kingdom. Retrieved at https://www.miltonkeynes.gov.uk/environmental-healthand-trading-standards/pollution/healthimpacts-from-municipal-waste- 
management on 14 October, 2013

Health and Safety Executive. 2007. Health hazards in the waste and recyclable industry. Waste15. Retrieved on 23 September, 2013 at www.hse.goc.uk/pubns /waste15.pdf

Huang, G.H., and Chang, N.B. 2003. The perspectives of environmental informatics and systems analysis. Journal of Environmental Informatics 1 (1), 1-7.

Majumdar, D., and Srivastava, A. 2012. Volatile organic compound emissions from municipal solid waste disposal sites: a case study of Mumbai, India. J. Air Waste Manage. Assoc. 62 (4), 398-407.

National Population Commission. 2008. Census Tables. Retrieved at http://www. population.gov.ng/files/nationalfinal.pdf . on 12th March 2013.

Nzeadibe, T.C. 2009. Solid waste reforms and informal recycling in Enugu urban area, Nigeria. Habitat Int. 33(1), 93-9.

Nzeadibe, T.C., and Iwuoha, H.C. 2008. Informal waste recycling in Lagos, Nigeria. Commun Waste Resour Manag. 9(1), 2431.

Oketola, A.A., and Akpotu, S.O. 2015. Assessment of solid waste and dumpsite leachate and topsoil. Chemistry and Ecology. 31 (2), 134-146.

Oyeyiola O., Babatunde A., Abiodun A., and Popoola E. 2011. Occupational Health hazard Associated with Dumpsite Scavengers and Highway Workers in Lagos Metropolies. Journal of Environmental Issues. 1, 13-21.

Patil, P.V., and Kamble, R.K. 2017. Occupational health hazards in street sweepers of Chandrapur city, central India. Int. J. Environ. 6 (2), 9-18.

Poulsen, O.M., Breum, N.O., Ebbehoj, N., Hansen, A.M., Ivens, U.I., van Lelieveld, D., Malmros, P., Matthiasen, L., Nielsen, B.H., Nielsen, E.M., Schibye, B., Skov, T., Stenbaek, E.I., and Wilkins, K.C. 1995. Sorting and recycling of domestic waste. Review of occupational health problems and their possible causes. Science of Total Environment. 168, 33-56.

Rana, R., Ganguly, R., and Gupta, A.K. 2017. Parametric Analysis of solid waste management in satellite towns of Mohali and Panchkula-India. J. Sol. Waste Technol. Manage. 43 (4), 280-294.

Rives, J., Rieradevall, J., and Gabarrell, X. 2010. LCA comparison of container systems in municipal solid waste management. Waste Management. 30, 949-957.

Rushton, L. 2003. Health Hazards and Waste Management. British Medical Bulletin. 68, 183-197.

Sawyerr, H.O., Yusuf, R.O., and Adeolu, A.T. 2016. Risk Factors and Rates of Hepatitis $B$ Virus Infection among Municipal Waste Management Workers and Scavengers in Ilorin, Kwara State, Nigeria. Journal of Health and Pollution. 6 (12), 1-6.

Suleman, Y., Darko, E.T., and Agyemang-Duah, W. 2015. Solid Waste Disposal and Community Health Implications in Ghana: Evidence from Sawaba, Asokore Mampong Municipal Assembly. J Civil Environ Eng. 5 (6), 202-

Tchobanoglous, G. and Kreith, F. 2002. Handbook of Solid Waste Management. Second Edition. McGraw-Hill Inc., New York.

Thakur, P., Ganguly, R., and Dhulia, A. 2018. Occupational Health Hazard Exposure among municipal solid waste workers in Himachal Pradesh, India. Waste Management 78, 483-489.

World Bank. 2012. What a Waste: A Global Review of Solid Waste Management. The World Bank Washington, DC, USA.

World Resources Institute. 1996. United Nations Environmental Program, United Nations Development Program. The World Bank, World Resources 1996-1997. The Urban Environment. Oxford: Oxford University Press. Retrieved July 26, 2014 at http://documents.worldbank.org/curate d/en/242141468739495153/pdf/multipage.pdf 